\title{
Moonstruck: Viewing the Moon in the Ottoman World of the Seventeenth Century
}

\author{
Firat $\boldsymbol{Y a s s a ~}^{*}$
}

Time is the only phenomenon that encompasses the past, present, and future, giving vitality to all living beings. Throughout history, people have tried to understand this phenomenon by determining its cycles and dividing them into segments. In pre-modern societies, the powerlessness of people against nature made them view time and space as closely connected (time-space continuum).

In traditional Ottoman society, it was thus difficult to measure time. People made calculations using lunar movements. Court astrologers observed the moon and stars, advising sultans when to hold imperial accession ceremonies, celebrate princely births and weddings, or launch ships. In larger towns, at least the prayer times could be determined with assurance: However, villagers were mostly aware only of the day, month, season, and year. Hence, the understanding of time was quite different on the higher and lower rungs of the social ladder.

In this paper, I attempt to answer the following questions: To what extent is it possible to measure time by studying the phases of the moon? What were the meanings that the Ottoman ruling class attached to the moon? For what reasons did ordinary people try to document in the qadi court at what time they saw the new moon, finding witnesses and having the court scribes record their testimonies? My sources are the qadi court records of Anatolian and Crimean cities, with additional information from travelogues and chronicles.

*Department of History, Faculty of Sciences and Literatures, Düzce University, Düzce, Turkey.

E-mail: yasafirat@gmail.com

The Medieval History Journal, 22, 2 (2019): 343-366

(C) The Autfior, $2019 \diamond$ Los Angeles/London/New Delfi/Singapore/Wasfington DC/ Melbourne

DOI: $10.1177 / 0971945819890447$ 


\section{Introduction}

Şeb-i yeldâyı müneccimle muvakkit ne bilir,

Mübtelâ-yı gama sor kim geceler kaç sâ' at. ${ }^{1}$

—Bosnalı Sabit Efendi

Until about twenty-five years ago, the concerns, feelings and experiences of ordinary subjects of the Ottoman sultans were not of much interest to mainstream historians. The latter felt closer to the sultan's officials than to his subjects, and therefore they concentrated on issues of interest to the courtly, military and bureaucratic elites. Thus, when it came to the concept of time, the secondary literature written in the late 1900s and early 2000s focused on court astronomers cum astrologers (müneccim). The scientific astronomers occupied centre stage, with the specialists in charge of determining the proper times for prayer (muvakkit) following close behind. These researches deal mostly with Istanbul as the centre of the empire and with the eighteenth and nineteenth centuries, while there are very few studies on earlier periods.

Historians of Ottoman science have used astronomical handbooks as their principal source, or if cultural historians, they have focused on the study of clocks, which became popular when military and political preoccupations made it necessary to measure time by minutes or even seconds. In recent years, however, scholars have increased their efforts to understand and interpret the experiences of the lower classes of Ottoman society. In this context, historians have attempted to assess the meanings attached to different objects and particularly, to discern the ways in which peasants made sense of the world that they inhabited.

At the same time, Ottoman historians have discovered that in the early modern world, astronomy and astrology (ilm-i nücûm) were often inseparable, and thus they have highlighted the contribution of astrologers to techniques of calendar compilation and time measurement. Salim Ayduz has traced the history of Ottoman timekeepers, and followed the process by which the chief astrologer (müneccim başı) became an institution. ${ }^{2}$

\footnotetext{
${ }^{1}$ How could those astrologers and timekeepers know the longest night! Ask a man griefstricken because of love, he knows the number of hours in a night!

${ }^{2}$ Aydüz, 'Osmanlı Devleti'nde Müneccimbaşılık Müessesesi'; Aydüz, 'Müneccimbaşı Takvimleri’.
}

- The Medieval History Journal, 22, 2 (2019): 343-366 
As for astronomy, a comprehensive doctoral thesis by Ahmet Tunç Şen has systematically evaluated the science of astronomy, its existence in the Anatolian world, and ultimately its position in the Ottoman palace. ${ }^{3}$ Şen has shown that the earliest calendars emerged as palace almanacs in the time of Mehmed I (1413-21). In addition, he has determined the manner of appointing the chief astrologers-cum-astronomers as well as their job descriptions. ${ }^{4}$

It is now apparent that the Ottoman sultans decided on 'the rightest time' to engage in critical projects after consulting sources other than astronomical or astrological calendars. Among these sources, the moon played a critical role. Unfortunately, studies of ilm-i nücûm have largely overlooked the lunar style, as they mostly focus on astronomy relevant to the stars and planets, the techniques of time measurement and the preparation of calendars, thus coming up with a one-sided and rather mechanical narrative. ${ }^{5}$

Therefore, in the current study, I attempt to find answers to the following questions: To what extent is it possible to measure time by studying the phases of the moon? What were the meanings that the Ottoman ruling class, at the highest level of society, attached to the moon? For what reasons did ordinary people try to document in the qadi court at what time, they saw the new moon, finding witnesses and having the court scribes put their testimonies on record? As sources, I will focus on the qadi court records of Anatolian and Crimean cities, with additional information from travelogues and chronicles.

In the early modern period, determining time was a complicated issue. Nights and days, formed by the rotation of the earth around the sun, shorten and lengthen in the course of a year; and this situation sometimes impeded efficient uses of both time and space. People regarded the hours between sunrise and sunset as daytime, while night began with sunset and lasted until sunrise. In other words, men and women determined morning, afternoon and evening by following the movements of the sun. ${ }^{6}$

${ }^{3}$ Şen, Astrology in the Service of the Empire.

${ }^{4}$ Ibid., 237.

${ }^{5}$ Meyer, İstanbul'daki Güneş Saatleri; Çam, Osmanlı Güneşli Saatleri; Dizer, ‘'̇slam’da ve Osmanlılarda Saat'; Özdemir, Ottoman Clocks and Watches; Behrens, 'An Ottoman Calendar (takvim) for 1740/41 AD'; Tunal,, 'An Ottoman Astrologer at Work'; Vatin, 'L'Homme d'état ottoman, maître du temps'; Blake, Time in Early Modern Islam.

${ }^{6}$ Hitzel, 'De la clepsydre à l'horloge, 14. 
Since apart from determining time during the day, the sun played the main role in the warming-up and cooling-down of the earth, the formation of the seasons, and the barrenness and revival of the soil, many languages conceived it as a feminine character. By contrast, the moon was masculine, appearing at night and dying away at sunrise. ${ }^{7}$ Even so, in seventeenthcentury Anatolian towns, the names derived from the word shams/şems (the sun) mostly designated men. In obvious reference to the moon, women bore names such as Ayperi, Aymelek or simply Ay, or else Kamer, the Arabic word for the moon; but the ambivalence becomes apparent when we remember that names such as Aydan and Aydogmuş designated men.

In the Crimean Khanate to the north of the Black Sea, the name Güneş, meaning 'sun' in Turkish was among the names given to women; and a princess of the Dulkadir in southern Anatolia appeared sometimes as Güneş and sometimes as Şems. ${ }^{8}$ At least in terms of naming, in the mental world of the Anatolian people there thus was no sharp gender distinction between the moon and the sun.

Although the words for 'sun' and 'moon' could be masculine or feminine according to the language at issue, the speakers of whatever language determined the time according to the movements of the sun and the appearances of the moon. Specifically, determining holy days and times was crucial not only for Muslim, but also for Christian and Jewish communities. Since religion encompassed almost every area of human life, religious principles and rituals played a dominant role in shaping existence. Moreover, shamanism and nature religions attached very similar meanings and concepts of holiness to both the moon and the sun. Human beings waited for the right moment/time that they considered holy in accordance with metaphysical assumptions, rather than arranging their

\footnotetext{
${ }^{7}$ It will suffice to present examples from one eastern and one western language. The word 'shams', used in Arabic for the sun, is a semai muennes word, which means it is grammatically a feminine, see Manzûr, Lisânü'l-Arab, 2324-26. By contrast, the word 'ḳamar' (moon) is a masculine word. See Ibid., 3735-37. In Latin, it was the opposite, as the word 'sol' meaning the sun was masculine and 'luna' meaning the moon was feminine. Compare Marchant and Charles, Cassel's Latin Dictionary, 325, 529.

${ }^{8}$ In the Anatolian qadi records, there are plenty of names including the moon and the sun. For samples, see Abac1, The Ottoman Judges and Their Registers, 42, 288; Crimean Court Records (hereafter CCR), vol. 13, f. 12; CCR, vol. 17, f. 38, CCR, vol. 20, f. 70; for the mosque founded by a Dulkadir princess see Kahramanmaraş, 'Hatuniye Camii (Şems Hatun Camii)'.
}

- The Medieval History Journal, 22, 2 (2019): 343-366 
affairs logically and through their own judgement: a sign of the power exerted by religion all over the world.

\section{Time Measurement and the Hours of Prayer}

Before the ready availability of mechanical clocks, Muslims arranged their work and rest according to prayer times. Praying in congregation in masjids and mosques divided time into dawn, early afternoon, late afternoon, sunset and night. In almost every Muslim city centre, there were mosques or masjids, large and small, and people would understand what time it was from the call of the muezzin. ${ }^{9}$ However, it is unclear whether there were many minarets in Anatolian villages located far from the city centres. Thus, peasants must have had greater difficulty in understanding what time it was than townspeople had, although such a problem might not have occupied their minds.

It is important to remember that the situation was similar in Christian communities centred on their churches: at certain times of the day, the sounding of bells provided a timeframe for work, sociability, and prayer. ${ }^{10}$ In short, in the early modern period, notions of time were vague all over the world. Furthermore, as the movements of the sun determined the times of prayer, it was difficult to establish when religious services should take place if the weather was gloomy and cloudy.

When it came to reckoning time, the appearance of the moon was as important as the movements of the sun. Almanacs, which notified certain European users of holy days and ceremonies, were not a commodity that seventeenth-century Anatolian peasants could even imagine. While villagers were probably aware of what day it was, they did not have enough information to determine exact dates and hours, using instead broad terms such as 'dawn', 'afternoon' and 'evening'. Even in official documents written by government officials, the exact date did not always appear. Often Ottoman bureaucrats preferred vague expressions such as

\footnotetext{
${ }^{9}$ King, In Synchrony with the Heavens, 468.

${ }^{10}$ Hitzel, 'De la clepsydre à l'horloge', 14-15; In the sixteenth and seventeenth centuries, the British learned about holy days and the course of time in general, by the extensive use of almanacs, which they called 'the annual calendar'. Between 1664 and 1666, more than 1 million almanacs appeared in print. See Chapman, 'Making Time'; Epstein, 'Business Cycles and the Sense of Time in Medieval Genoa', 245; Glennie and Thrift, Shaping the Day, 248-49.
} 
evâil (the first 10 days of a month), evâsit (from 11th day to the 20th day of a month) and evâhir (the last 10 days of a month).

The appearance of the new moon meant the end of the old month and the beginning of a new one; but beyond this mundane role, the moon served as a basic motif in the legend accounting for the establishment of Ottoman rule. In Osman's dream, the moon that rises from Sheikh Edebali's chest means a new beginning when it enters Osman's chest. A large plane tree and springs gushing under the tree appear with the moon. Indeed, the collapse of the Anatolian Seljuk State is not an end, for a new polity has been born 'in the sign of the moon'. In many cases, sultans observed the moon and stars before deciding when to hold imperial accessions ceremonies, or celebrate princely births, weddings, or the launching of ships. Especially, when sultans and viziers decided to go on a campaign, they typically would wait for a sighting of the new moon. ${ }^{11}$

\section{Holiness and the Moon}

From the first epochs of history, humankind has assigned sacredness to inaccessible objects, mostly linked to 'the sky' or 'the heavens', and thus beyond their power and control. Generally, people tried to shape their lives by interpreting the movements of the sun, the moon and the stars according to whatever belief systems they happened to hold, both by predicting the future and by creating short-term calendars. People attempting to understand time and seasonal changes and organise their lives accordingly have linked their calendars to the appearance of the moon. ${ }^{12}$ As for the first signs that humans were trying to understand time by observing the moon, they have come from archaeological excavations in Ukraine: people have drawn the changing silhouettes of the moon, such as a crescent and a full moon, on a mammoth horn, a piece of artwork that may belong to the Neolithic Age. ${ }^{13}$

Throughout history, the moon has been an important phenomenon in people's lives. In the course of a month, the moon takes on different silhouettes. The new moon, in the shape of a crescent, changes its

\footnotetext{
${ }^{11}$ İlhan, The Astrology of the Ottoman Empire.

${ }^{12}$ Timothy Paul Grove has conducted a detailed study showing that the meanings attributed to the moon are similar in a wide area ranging from Mesopotamia to the Caucasus: Grove, A Star in the East.

${ }^{13}$ McClellan and Dorn, Science and Technology in World History, 14.
} 
appearance with the rays received from the sun, it gradually becomes bright and enlarged, takes the shape of a full moon, then disappears and becomes invisible during three dark nights. Mircea Eliade likens this cyclical process to the birth, growth, decline and end of a species. ${ }^{14}$ Thus, the moon, in constant renewal, offers life together with its rebirth; and people living in ancient societies thought that analogous to moonrise and sunset, the universe was in constant renewal.

This understanding is not peculiar to the thought of primitive societies: the belief system of the ancient Turks attributed holiness to celestial objects, because God is at the top of the sky, and the objects in the sky are indicative of God's power. In shamanism and nature beliefs, people regarded the sun as a woman and the moon as a man. The best example of this conception are the sayings involving 'mother sun' and 'father moon'. ${ }^{15}$

From the early middle ages to the seventeenth century, there probably were no dramatic changes in the meanings attributed to the moon, at least not in the Ottoman world and in the sphere of time determination. Even so, caution is of the essence, because our knowledge is so limited.

Whatever the situation may have been, it is worth retaining that the symbol of the Islamic faith is the crescent, the new moon, which believers view as a beginning sanctioned by the Deity. The Islamic calendar is the lunar calendar, and the phases of the moon determine all sacred days and ceremonies. For instance, pilgrims go to the city of Mecca to perform their Hajj pilgrimage at a time specified by the lunar calendar, while the appearance of the crescent determines the beginning and final dates of the Ramadan fast. ${ }^{16}$ There are references to this issue in the Koran, the holy book of the Islamic religion. For example, the Bakara surah says: 'They ask you about crescents. Say, they are time measures for people and pilgrimage'. ${ }^{17}$

In addition, the miracle of Muhammad, the prophet of Islam, shows a close connection with the moon. When the latter became prominent and turned into a full moon, he prayed to God in front of the nonbelievers to make them believe that he was a prophet, and because of his prayer, Muhammad could divide the moon in half with his finger. ${ }^{18}$

\footnotetext{
${ }^{14}$ Eliade, Cosmos and History the Myth of the Eternal Return, 87.

${ }^{15}$ Kıyak, ‘İslamiyet’ten Önce Türklerde Güneş ve Ay ile İlgili İnanışlar’, 136.

${ }^{16}$ Kadoi, 'Crescent (Symbol of Islam)', 47.

${ }^{17}$ Kuran, Bakara Suresi, 2/189, https://kuran.diyanet.gov.tr/tefsir/sure/2-bakara-suresi.

${ }^{18}$ Abdulsater, 'Full Texts, Split Moons, Eclipsed Narratives'.
} 
When the Prophet Muhammad and his community migrated from Mecca to Medina, they waited for the new moon to appear before entering the latter city. ${ }^{19}$ In accordance with Islamic tradition, rulers and viziers thus preferred to have the crescent form of the moon appear, before as noted, taking action in critical events involving the whole society, such as war and migration.

As these narratives show, the moon has been a sanctified object in almost every period. Given its constant renewal, people think that the new moon will be propitious to new hopes and new beginnings. Over a wide expanse of territory, various religions have regarded the new moon as auspicious. At least hypothetically, prehistoric societies have shared this belief, as did early medieval Central Asians, adherents of shamanism as well as Muslims throughout the centuries.

\section{Over the Centuries: The Changing Moon as a Means of Measuring Time}

Jacques Derrida, one of the great philosophers of the twentieth century, considers Shakespeare's memorable tragedy Hamlet as a base for his reflections on the 'time' that 'is out of joint'. He concludes that time is the thing that is 'the holding together of the disparate itself' ${ }^{20}$ Indeed, with the power it possesses, time ties the object and the subject tightly to the outside world. So much so that time is an innate necessity, which one inherits and never needs to learn later on. The concept of time, which Derrida emphasises, has continued to be as important as the physiological needs of a human being, not only in the author's own time, but in almost every age as well. After all, every period and every society has its own conception of time. We cannot separate the latter from its place, society and period, since it is specific to them. Therefore, the integrity of time and space gains particular gains importance at this specific point. ${ }^{21}$

Inaccessible to the technical aids and achievements that surround us, understanding the past is a very complex and difficult task. As mentioned

\footnotetext{
${ }^{19}$ Mubarakpurip, When the Moon Split, 136.

${ }^{20}$ For detailed information on Marx's definition, see 'not to maintain together the disparate, but to put ourselves there where the disparate itself holds together, without wounding the dis-jointure, the dispersion, or the difference, without effacing the heterogeneity of the other'. Derrida, Specters of Marx, 34-35.

${ }^{21}$ Kern, The Culture of Time and Space 1880-1918, 10-20.
} 
earlier, Muslim societies calculate time during the day according to the movements of the sun, and prepare the calendars that show the long-term course of time according to the appearance of the moon. David A. King has pointed out that in the Islamic world, time calculations with the lunar calendar have been a subject of debate for centuries. Muslim astronomers have written a multitude of works on the measurement of time and created various calculations and charts. Thanks to the tables called $z i j$ (astronomical handbooks with tables), which contain lunar measurements, they have been able to determine when holy days and ceremonies should begin and when they should end. ${ }^{22}$

The phases of the moon, namely the new moon, the first crescent, the first quarter, the second quarter, the full moon, the third quarter, the last quarter and the last crescent were all important in the calculation of month-based time. Astronomers could follow the changing silhouettes of the moon to determine the current day of the month. Ordinary people who were not interested in astronomy knew that the new moon coincided with the first day of the month, and the full moon coincided with the 14th day of the month. ${ }^{23}$ Obviously, accurate time measurement was more important for people in the palace and its environs, officials working in various state bureaus, traders and money-lending pious foundations, than it was for an ordinary peasant or artisan.

Seasonal transitions and cloudy weather can impede the observation of lunar movements. Therefore, zijes were one of the main reference sources for astronomers, allowing them to predict the movements of the moon and thus to state when prayers and religious celebrations should take place. In the eighteenth and nineteenth centuries, there were approximately 200 zijes produced by medieval astronomers. ${ }^{24}$ Many scholars might accept and use a given $z i j$; but sometimes, theoretical knowledge would not work in practice. For this reason, in certain centres, patrons established so-called timekeeper offices, to prepare revised zijes and improve measurement techniques. In the fifteenth and sixteenth centuries, the Zîj-i Illhâni was in use as an astronomical handbook, but as time passed, discrepancies in the calculation of holy days and ceremonies led to its abandonment. To replace

\footnotetext{
${ }^{22}$ King, 'Lunar Crescent Visibility Predictions in Medieval Islamic Ephemerides', 233-34.

${ }^{23}$ Yücel, 'Hilâl'; Çelebioğlu, 'Bedir'.

${ }^{24}$ King, 'Lunar Crescent Visibility Predictions in Medieval Islamic Ephemerides', 234.
} 
it, the Samarkand Observatory produced the Zîj of Ulugh Bey. Known as $Z \hat{j} j-i$ Cedîd-i Sultanî, it was in use for a long time. ${ }^{25}$

We do not know whether before the early fifteenth century, Ottoman scholars produced their own calendars. In fact, when we consider that the earliest official documents, for instance, tax registers or the protocols of qadi courts date to the first half of the fifteenth century, it is not surprising that the first extant calendar dates to $1421 .{ }^{26}$ Tunç points out, that astrologers were not the only calendar makers, drawing attention to the existence of some local calendars in addition to the palace-centred variety. After all, in the Ottoman archives, he has found calendars whose makers had used different $z i j e s .{ }^{27}$ Thus, there must have been müneccims or muvakkits active in the provinces; unfortunately, we do not know how popular their works were. In some city mosques, including Istanbul and Mecca, a room was available that the muvakkits could use to observe the sun and the moon. Thus, the seventeenth-century traveller Evliya Çelebi noted that there was a lookout in Okmeydanı on the outskirts of Istanbul, where people would wait for the crescent of Ramadan to appear. Once that had happened, guards lit fires on top of the lookout, and garrison soldiers fired cannons to announce the news to the people of the city. ${ }^{28}$

Evliya Çelebi recorded a further lookout in Mecca, reporting that when Muhammad was a child, there was a drought in this city. 'Abd al-Mutțalib who prayed for rain with the Quraysh people, asked for water for the sake of the orphan Muhammad. When the Prophet prostrated himself, Allah accepted his prayer and the rain began. Later people built a place of worship on this site, which the Meccans used as a lookout. Evliya Celebi provided the following description:

In this place, there is a rock with a pit in it. On the west side of that pit in the rock, there are notches. On the first day of every month, the crescent is visible from these places and never wanders. It is a strange miracle. If there is a cloud in the air, there are Mecca muvakkits who look from that pit and of course, the crescent is evident. ${ }^{29}$

${ }^{25}$ Şen, 'Rasattan Takvime', 230.

${ }^{26}$ Ibid., 232.

${ }^{27}$ Ibid., 235.

${ }^{28}$ Evliya, Evliya Çelebi Seyahatnamesi Topkapı Sarayı Kütüphanesi Bağdat 304, 20.

${ }^{29}$ Evliya, Evliya Çelebi Seyahatnamesi Topkapı Sarayı Kütüphanesi Bağdat 306, 381.

- The Medieval History Journal, 22, 2 (2019): 343-366 
While calendars were many, it is hard to judge their accuracy. Sometimes even the greatest specialists made mistakes. Salim Aydüz has referred to Mustafa Zeki Efendi, the chief müneccim of the palace in the early 1700s. Although this senior officer had worked in this position for fourteen years, he lost his job when it turned out that he had many times miscalculated the first day of Ramadan, which was the most important duty of the chief müneccim. Moreover, this office-holder prepared a table of prayer times known as the imsakiye, which he presented to the highest dignitaries of the empire beginning with the sultan and the grand vizier, before the beginning of Ramadan. ${ }^{30}$

People expected the muvakkits to know the times of worship well, for they needed to inform the muezzins about prayer times and regularly check the time in the course of the day. ${ }^{31}$ Theoretically, müneccims and muvakkits should have had an understanding of astronomy and mathematics. However, such well-informed officials were not very common, as we can gather from the fact that the surviving calendars come from a limited number of localities.

\section{What a Legend Says to Ottoman Historians}

From the earliest periods known to history, human beings have increased their power and reputation by attributing holiness to important works that they undertake or will undertake in the future. Frequently, people in leadership positions will claim the sanction of divine power through signs and miracles. People invoke myths when establishing a new polity, granting sovereignty to a prince, deciding to settle in a given region or taking some other critical decision. Thus, the enterprise is part of an overarching cosmic world, though the form of legitimisation, which normally involves links with the Deity, will differ from place to place and from period to period.

In the fourteenth century, when there was no printing press, legends spread by word of mouth, and therefore, there are usually many different versions of a given story. A famous example, mentioned earlier on, concerns the dream of Osman Bey (d. 1326) about the establishment of the Ottoman Empire, which even has featured in the title of a recent

\footnotetext{
${ }^{30}$ Blake, Time in Early Modern Islam, 97.

${ }^{31}$ Aydüz, 'Osmanlı Devleti'nde Müneccimbaşılık Müessesesi', 72.
} 
comprehensive history. ${ }^{32}$ Many chroniclers from Aşıkpaşazade to Neşri include Osman Bey's dream, and here is Aşıkpaşazade's version:

Osman Gazi prayed and cried for a short while. Overcome by drowsiness, he lay down and slept. He saw that among the people, there was a beloved sheikh. His many miracles were apparent, and all the people followed him devotedly. He was a dervish, but his dervish qualities were within him, hidden \{to outsiders\}. He had plenty of worldly possessions, comforts and goods, and knowledge and followers as well. He always had guests and his house was never empty. Osman Gazi himself would be a guest of this holy man from time to time.

As Osman Gazi slept, he saw in his dream that a moon arose out of this holy man's breast and entered his own. A tree emerged from his belly, its shadow covered the whole world, and mountains formed under its shadow with water emerging from beneath these mountains. Some people drank of this water, some watered their gardens and fountains flowed. Then he woke up from sleep, came \{out\} and informed the Sheikh. The Sheikh said, 'my son Osman, good news to you, the Almighty God as given \{the quality of sultan to you and your descendants. Moreover, my daughter Malhun will be your wife'; he said and at that moment gave his daughter in marriage to Osman Gazi. ${ }^{33}$

Contemporary historians studying the establishment of the Ottoman Empire have dealt with different versions of this dream. ${ }^{34}$ However, hardly any authors emphasise the moon motif, although, when we look closely at the dream, there is a moon at the beginning of everything. While the dream features a dervish, a tree, and a source of life-giving water, none of these things could exist without the moon, in shamanist belief, the harbinger of fertility, renewal, and good things. ${ }^{35}$ When in the dream, the moon entered Osman Bey's chest, the tree, which is the symbol of sovereignty, emerged, then mountains, waters, rivers, and gardens formed and became the sources of life.

Considering these mythological symbols, Halil İnalc1k has connected Osman's dream to Turkish-Mongolian traditions, emphasising the

${ }^{32}$ Finkel, Osman's Dream.

${ }^{33}$ Aşık Paşazade, Osmanoğulları'nın Tarihi, 57-58; for a different version see Neşri, Kitâb-ı Cihan-nümâ Neşrî Tarihi, 81-83.

${ }^{34}$ Imber, The Ottoman Empire, 1300-1650, 124; Lindner, Nomads and Ottomans in Medieval Anatolia, 37; Finkel, Osman's Dream, 2.

${ }^{35}$ Eliade, The Sacred \& The Profane, 156-57.

- The Medieval History Journal, 22, 2 (2019): 343-366 
effectiveness of basing the authority of a newly established polity on a divine source. ${ }^{36}$ The function of the moon in this dream is not only to symbolise abundance, fertility, and good things to happen, but to initiate a relationship as well. After all, Sheikh Edebali, who interprets the dream, also announces the marriage of his daughter to Osman Bey. Therefore, the moon serves to unite a man and a woman, who will start a family. Apart from the traces of shaman culture, the dream refers to the moon motif in Islamic faith, and thereby declares the future sultan to be an Islamic ruler. In a more narrowly political sense, we can view the moon, which constantly changes its silhouette and renews itself, as a symbol of resurrected political power after the fall of the Anatolian Seljuks. Ultimately, the moon, especially when taking the form of a rising crescent, indicates a belief that whatever action is taken, will continue.

\section{A Divine Sign for the Sultans: The Moon and the Night Battles in the Ottoman Empire}

For the Ottomans, whose cultural codes included the concept of harmony, a notion significant in both the Central Asian Turkish traditions and the Islamic faith, celestial events were of great significance. The rotation of the moon around the earth, the planets, the stars, as well as the movements of the sun, and solar or lunar eclipses, all these phenomena had something to say to the inhabitants of the Ottoman Empire, from the ruling class to peasants and nomads.

However, it was not easy to decipher the meaning of such heavenly signs. For an army gathered on the battlefield, a change in the night sky might mean 'Get ready to attack enemy territory!' However, it was often difficult for the sultan to make decisions of this kind, and a major reason for the presence of a chief müneccim at the Ottoman court was to assist sultans and viziers in making such decisions. For this reason, müneccims reported celestial events to palace officials. They calculated on which day of the following month a crescent moon or a full moon would appear, and at what time of year the eclipse of the moon would occur. Many such reports still exist, and I will investigate whether there were differences

${ }^{36}$ İnalcık, ‘Aşı1kpaşazâde Tarihi Nasıl Okunmalı?’ 132. 
between historical periods, in terms of consulting the position of the moon before making critical decisions.

The first case that we will examine concerns the conquest of Istanbul. Mehmed II had given orders to build the Boğazkesen Fortress on the European shore of the Bosporus, known today as Rumeli Hisarı. Tursun Bey, a sixteenth-century chronicler, emphasises that it was possible to watch the moon and the stars from the bastions of the Bogazkesen Fortress. ${ }^{37}$ Even in a period of superlative physical power, the Ottoman sultans thus consulted the phases of the moon, especially crescent and full moon, to determine the best time for action - and apparently, the Byzantines shared this belief. Nicolò Barbaro, an Italian traveller, reported the conquest of Istanbul in the following terms:

On the 22nd of May a strange and awkward sign appeared in the sky, which said that the empire, which Constantine, the esteemed emperor, was $\{$ so $\}$ proud of, was about to end. It was like this: The moon was born in the first hour after sunset, \{when\} it was time for a full moon. Therefore, \{people\} expected the moon to be full. The moon, however, was born very small, as if it was three days old. The air was clear and cloudless, as clean as a crystal. The moon remained that way for four hours, and then slowly became a full circle. It turned into a full moon in the sixth hour of the night. When the Emperor and his nobles, we Christians and 'faithless' Turks alike, saw this extraordinary sign, everybody became very concerned, because according to the prophecy that the Byzantines believed in, Constantinople would not fall, until the full moon signalled \{its demise $\}$. Indeed, it happened in this fashion. ${ }^{38}$

The Byzantine historian Doukas has described this incident as a lunar eclipse, noting that many prophecies about the fall of the Byzantine Empire were current among nearly all members of society. These predictions commonly featured the lunar eclipse and then the belated appearance of the full moon. Probably, Mehmed II was aware of these prophecies too, and he must have timed the attack on the gates of Constantinople accordingly. ${ }^{39}$ Doukas has emphasised that the

\footnotetext{
${ }^{37}$ Tursun, Fatih'in Tarihi (Tärih-i Ebul Feth), 44; Tursun, The History of Mehmed the Conqueror, 33. In addition, see Doukas, Decline and Fall of Byzantium to the Ottoman Turks, 304.

${ }^{38}$ Barbaro, Kostantiniye'den İstanbul'a, 174-75.

${ }^{39}$ Halil İnalcık points out that during the conquest of Istanbul, Akşemseddin engaged in fortune telling from the Koran: İnalcık, Osmanl Tarihinde Efsaneler ve Gerçekler, 89.
}

- The Medieval History Journal, 22, 2 (2019): 343-366 
Byzantines became demoralised and accepted defeat in the face of this extraordinary celestial event. ${ }^{40}$ Thus, similar to their Ottoman opponents, Byzantine Christians regarded lunar phenomena as 'portents', or signs presaging important events. To put it bluntly, both Ottomans and Byzantines gave every impression of being 'moonstruck' ${ }^{41}$ For, even if physically equipped to embark on a campaign, the leaders of both the Ottoman Empire and of Byzantium chose to act according to these 'portents' rather than rely on their own judgement.

After the conquest of Istanbul, we find a similar prophecy, once again relating to a lunar eclipse, in a report about the Battle of Çaldıran (1514). Writing over a hundred years after the event, the Ottoman official historian and Chief Müneccim (Müneccim Başı) Ahmed Dede (1631-702) mentioned a solar eclipse, noting that on 28 Cemaziye'1 ahir 920 (20 August 1520), a Saturday, a solar eclipse occurred. The Ottoman side interpreted this event as a divine sign of the future defeat of the Safavid Empire and the victory of the Ottoman sultan. Müneccim Baş1 emphasised that with this incident, the motivation of the soldiers increased and they became impatient to meet the enemy. ${ }^{42}$ Thus, people attributed supernatural qualities to the eclipses of sun and moon even in the 1500 s and 1600 s.

The crescent functioned as a particularly favourable sign, as apparent from a report concerning a raid by the Crimean Tatars. However, information about this event has come down to us in an unfamiliar form, namely a report in The London Gazette, launched in England in November 1665. In an edition dated 1671, we find the following piece of news:

Warsaw, July 31. From Caminiec (Kamianets) they write that they had advice there from Wallachia, that the great Chan of Tartary was ready to march towards those parts, with a very powerful army, and that he only expected the new moon (a time those people superstitiously observe) to favor their designs and from the General Sobietski (Sobieski) here are letters bringing the like unwelcome

${ }^{40}$ Doukas, Decline and Fall of Byzantium to the Ottoman Turks, 311-12.

41 The moon sometimes falls under the shadow of the earth as it goes around in its own orbit, and this stage usually occurs in the full moon phase. When the eclipse occurs due to the proximity of the moon to the earth, low tides occur in the waters and nature's order changes for a short time. (See Oxford Reference, 'Eclipse': https:// www.oxfordreference.com/view/10.1093/oi/authority.20110803095740827).

${ }^{42}$ Müneccimbaşı Ahmed Dede, Sahaif-ül-Ahbar fì Vekayi-ül-a sâr r, 461-62. 
news, of the Tartars being on their way towards Bar, which is feared they may have intentions to besiege, if not timely relieved. ${ }^{43}$

The report in the Gazette stating that the Crimean Khan with a powerful army was intending to raid Ukraine lands and the soldiers were waiting for the crescent before taking action is a great example of the force of 'portents' even at this late date. As for the Ottoman campaign against Vienna in 1683, Kara Mustafa Pasha's army waited for the crescent moon to appear as well, although this time it did not bring them much success. ${ }^{44}$ Thus, from the conquest of Istanbul to the siege of Vienna, Ottoman sultans, their commanders and their soldiers continued to attach special meaning to the new moon, regarding its appearance as a good time for the army to take action. In other words, the prestige of the moon, and that of the interpreters of lunar movements the müneccims, stood high, from the initial decision to go to war to the planning of a military campaign. Despite the course of centuries and changing theatres of war, this notion persisted without much change.

\section{The Moon in the Ottoman Courts of Law}

At present, we have a certain number of studies on the views of sultans and elites concerning the movements of the moon and its role in measuring time. However, given the state-centred character of a large section of Ottoman historiography, we still know very little about ordinary people living in settlements far from administrative centres, whose concepts of time and place must have been different in many respects. Even so, artisans, peasants and nomads used the moon and the sun as essential elements for understanding time.

One of the most valuable sources on this subject are the records of the many sharia courts operating in Ottoman towns and cities. At certain times of the year, people from different walks of life came to court to record celestial or natural events: from severe storms to eclipses of the sun and moon, from fields ruined by locusts or grasshoppers to snow or hail falling in summer, from the blossoming of certain trees to the deaths of animals because of severe cold. ${ }^{45}$ Sometimes clerks reported such incidents on their

${ }^{43}$ The London Gazette.

${ }^{44}$ Wheatcroft, The Enemy at the Gate, 204.

${ }^{45}$ Özdemir, 'Çeşitli Kültürlerde Zamanı Ölçme Faaliyetleri', 65.

- The Medieval History Journal, 22, 2 (2019): 343-366 
own initiative; and sometimes people came to court explicitly asking that these events should enter the record. In particular, townspeople had the appearance of the crescent moon entered into the registers of the qadi's court, for this phenomenon indicated the beginning of the holy month of Ramadan as well as that of Receb and Şaban, which enjoyed some religious prestige as well. In addition, observing the phases of the moon allowed people to establish the time of the holy nights of Regaib, Mi'rac and Berat. In a society where villagers mostly learned about events unrelated to the agricultural calendar when attending the town market, and where people easily missed the rise of the moon due to bad weather, a court record helped to eliminate uncertainty. However, not every qadi register provides information of this kind, and many people must have depended on what their more knowledgeable neighbours told them.

When recording the appearance of the moon in seventeenth-century court registers, credibility was a pressing problem. Put differently, the judge wanted to know whether the witness had clearly seen the crescent. To facilitate checking, the scribes took down at what time the crescent moon had supposedly appeared, who had seen it, and whether the witness who brought it to the court's attention, was a reliable person. To avoid later disputes, the qadi and/or his scribes had to weigh these factors very carefully. Thus, for example, on 28 Şaban 1077/12 February 1668, a man named Ali Kaya ibn Mehmed, inhabiting the Yenice quarter of Kayseri, came to the qadi's court and reported that on the evening of 29 Şaban, he had seen the crescent of Ramadan from the roof of his house. He claimed that he was not the only witness, and that a person named Miyase had been there as well. However, Miyase had not come to court. According the sharia as interpreted by Ottoman jurists, the qadi then asked Ali Kaya to swear that he had seen the moon, as was the practice if a claimant had no witnesses.

However, before deciding on the beginning of Ramadan in Kayseri, the qadi instructed an official named Mevlana Resul Efendi to investigate whether the witness was trustworthy. Resul Efendi asked the imam and community of the quarter where Ali Kaya lived. According to the information obtained, Resul Efendi became convinced that Ali Kaya was reliable and of a character appropriate for bearing witness in court. Therefore, the qadi decided to announce the beginning of Ramadan fasting by asking the local military commander to shoot off his cannons. ${ }^{46}$

\footnotetext{
${ }^{46}$ Şahin, ‘77/1 Numaralı Kayseri Şer’iyye Sicili,’ 60.
} 
This record shows that in accordance with Hanefi religious law, which considers witness testimony superior to written evidence, the judge decided on the beginning of Ramadan after having a reliable person swear that he had seen the new moon. The qadi does not seem to have consulted the calendars created by local müneccims. Sometimes when needing to determine the day and month of a given event, the judges consulted imams and muezzins, whom they probably deemed more reliable than ordinary people.

Some observers recorded the day on which they had seen the crescent in the months of Şevval, Zilkade and Zilhicce as well, because with this evidence, the qadi could calculate the exact date of the upcoming Feast of Sacrifices (Kurban Bayram1). From the cities of Anatolia and Crimea, we possess many documents to this effect. Thus, for example, Bekir ibn Arab Yusuf, a resident of Bahchesaray in Crimea, informed the local court that he had seen the crescent on 1 Zilhicce 1078/13 May 1668. Then, when three muezzins named Bodur Mehmed ibn Salih, el-Hâc Mehmed and Mustafa ibn Ibrahim came to the court and declared they had seen the crescent as well, the judge saw no need to investigate the reliability of Bekir because the testimony of the muezzins sufficed. ${ }^{47}$ Another example concerns Muezzin Ömer ibn Abdulkadir, who on 1 Şaban 1077/27 January 1667 informed the court that he had seen the Şaban crescent on Tuesday evening. When it was necessary to determine the incidence of holy days and ceremonies, people quite frequently turned to 'religious specialists': in Ankara, an imam named Cafer Halife from the Eskicizade quarter appeared before the court and testified that he had seen the crescent. ${ }^{48}$

Some people used their observation of the crescent moon to determine when a debt fell due, although such cases are not very frequent. An interesting instance comes from the Istanbul court records. Mehmed Çelebi ibn Abdullah, a resident of the Nevbahar Quarter who inhabited the Çifteayak Madrasa near the Semaniye Madrasa in the Fatih area of intra muros Istanbul, acted as the legal representative of İbrahim Çelebi ibn Abdullah. Mehmed Çelebi sued Hasan Beşe ibn Abdullah, because İbrahim should have received 10 gurus for the scarves that he had previously delivered: the debt was payable within 40 days.

${ }^{47} \mathrm{CCR}$, vol. 11, f. 2; CCR, vol. 11, f. 83; CCR, vol. 31, f. 77. Many more examples exist.

${ }^{48}$ Çınar, H. 1020-1021 Tarihli 13 Numaralı Ankara Şer'iye Sicili, 247.

- The Medieval History Journal, 22, 2 (2019): 343-366 
On 10 Şaban 1077/5 February 1667, Mehmed Çelebi appeared before the qadi to collect 10 guruş from Hasan Beşe. The latter acknowledged his debt but denied that 10 Şaban was the date of payment, whereupon the qadi asked the plaintiff for evidence. Mehmed Çelebi introduced two people named Ahmed Efendi ibn İbrahim and Ömer Efendi ibn Ali, who stated that they had seen the crescent of the month of Receb rising over their dwelling on Sunday, the last day of Cemâziyel ahir. The witnesses swore that by the end of Receb, 30 days had passed and that on 10 Şaban, the debt had been outstanding for 40 days. Once again, the qadi accepted the testimony on the appearance of the crescent and ruled that Hasan Beşe should pay his debt on time. ${ }^{49}$

In this record, which is a good example of how ordinary people calculated time by means of the moon, it is noteworthy that madrasa officials solved the problem. In fact, those who knew the time were usually people who had enjoyed an above-average education. Nurcan Abacı has discussed a case concerning a divorced woman from Bursa named Fatma. The latter wanted to marry her new suitor and applied to the court in order to shorten the legal waiting period of three months, asserting that she had had three periods in 40 days. Abac1 has tried to determine how Fatma and her relatives may have calculated the time since her divorce, perhaps by knotting a rope or throwing bits of gravel from one saucepan into another; for they probably knew quite well that the sharia demanded that a divorcee should have menstruated three times before remarrying. ${ }^{50}$

Likely, it was much more difficult for ordinary people to calculate time, than for religious officials such as imams and madrasa teachers, or even for people with semi-official honorifics such as çelebi, efendi, ağa, and beşe.

\section{Conclusion}

In this study, we have discussed how the subjects of Ottoman sultans used the changing phases of the moon for time measurement. In this undertaking, we have tried to do more than just catalogue attempts to establish the correct time by astronomical calculations. Rather, we have attempted to reveal the ways in which state officials and ordinary people

${ }^{49}$ Günalan, İstanbul Kadı Sicilleri, 651.

${ }^{50}$ Abacı, 'Koca Olsun Bu Gece Olsun', 694. 
perceived time, to understand the meanings that their belief systems assigned to the moon, and to discern the effects of these assumptions upon the lives of elite and non-elite people alike. In many cases, the beliefs of the sultans' subjects derived not only from Islamic tenets but from Central Asian Turkish traditions as well.

It is a significant result of our study that between the conquest of Istanbul in 1453 and the siege of Vienna in 1683, the meanings attributed to the moon did not change very much. As a basic element of mythical beliefs and prophecies, the moon appeared in the form of a crescent, a full moon or else as an eclipse; and belief in its power continued into the late seventeenth century. Throughout, the new moon always meant a 'beginning and renewal' in cosmic understanding. In this respect, the Ottomans conformed to a millennial tradition, as similar beliefs had existed in many tribes and empires, from Babylon to the Central Asian Turks, the Mongols, and the Byzantines.

Although the Ottomans of the 1400 s and 1500 s possessed the physical, intellectual and social preconditions for successful campaigns and conquests, they attempted to enhance their chances of success by harnessing the power of the moon. Moreover, this attitude changed but slowly, for in certain sources covering the nineteenth century, we still can discern traces of the practices discussed in this study.

Since in any society, the powerful decide what 'the right time' will be, the venues where Ottoman sultans and viziers made time measurable were located in the centres of their empire. Müneccims and muvakkits officiated in towns and especially in cities, rather than in the countryside. In areas far away from the larger towns, where there were no qadi courts to fix the rising of the crescent moon, time became uncertain. We frequently observe that, when someone saw the crescent and reported it to the qadi's court, or when something very important happened, people knew what day of the week it was, but they did not know the exact date.

Furthermore, qadi courts often dated their records not by the day on which a given event had occurred or come to the knowledge of the court, but by ten-day intervals (evâil, evâsıt, and evâhir) that made up the month under discussion. As Istanbul's qadi registers give more exact dates for court cases than the records of many Anatolian cities do, we may assume that near the centres of power, people understood the passage of time more clearly than was true of the inhabitants of outlying areas. 
Throughout the Ottoman world, ordinary people tended to understand and measure time according to the movements of the moon, which enabled the more astute and/or educated among them to determine the holy times of Islam, such as the beginning and end of Ramadan and the date of the Feast of Sacrifices. Both the courts and ordinary people preferred to hear from witnesses who had seen the moon - if they had not been able to observe the crescent with their own eyes. Calendars, by contrast, the manifestations of astronomical knowledge, played only a minor role.

\section{Declaration of Conflicting Interests}

The author declared no potential conflicts of interest with respect to the research, authorship and/or publication of this article.

\section{Funding}

The author received no financial support for the research, authorship and/ or publication of this article.

\section{References}

Abacı, Nurcan. 2018. 'Koca Olsun Bu Gece Olsun: Kırk İki Günde Üç Kez Âdet Gören Bursalı Fatma'nın Hikâyesini Kurgulamak (17. Yüzyıl)', in Âb-ı Hayât'ı Aramak, Gönül Tekin'e Armağan, edited by Ozan Kolbaş and Orçun Üçer. İstanbul: Yeditepe Yayınevi: 689-99.

- 2007. The Ottoman Judges and Their Registers: The Bursa Court Register B-90/295 Dated AH 1081/AD 1670-71. Cambridge, MA: Harvard University.

Abdulsater, Hussein. 2018. 'Full Texts, Split Moons, Eclipsed Narratives: The Literary History of a Cosmological Miracle' Narrative Culture, vol. 5 (2): 141-86.

Âşık Paşazade. 2003. Osmanoğulları'nı Tarihi. Edited by Kemal Yavuz and M. A. Yekta Saraç İstanbul: MAS Matbaacı1.

Aydüz, Salim. 2000. 'Müneccimbaşı Takvimleri ve Tarihi Kaynak Olarak Değerleri', Cogito, vol. 22: $132-44$.

—. 2003. 'Osmanlı Devleti'nde Müneccimbaşılık Müessesesi', Belleten, vol. 70 (257): 1-96.

Barbaro, Nicolò. 2007. Kostantiniye'den Istanbul'a. Translated by Muharrem Tan. İstanbul: Moraliye Yayınlar1.

Behrens, Gerhard. 2011. 'An Ottoman Calendar (takvim) for 1740/41 AD', Middle East Studies Online Journal, vol. 4 (2): 1-90. 
Blake, Stephen. 2013. Time in Early Modern Islam: Calendar, Ceremony, and Chronology in the Safavid, Mughal, and Ottoman Empires. New York, NY: Cambridge University Press.

Çam, Nusret. 1990. Osmanlı Güneşli Saatleri. Ankara: Kültür Bakanlığı Yayınları.

Çelebioğlu, Amil. 1992. 'Bedir'. TDV İslâm Ansiklopedisi, vol. 5: 324-25.

Chapman, Alison A. 2007. 'Making Time: Astrology, Almanacs, and English Protestantism', Renaissance Quarterly, vol. 60 (4): 1257-90.

Çınar, Hüseyin. 1993. 'H. 1020-1021 Tarihli 13 Numaralı Ankara Şer'iye SiciliTranskripsiyon ve Değerlendirme’. Master Thesis: Gazi Üniversitesi Sosyal Bilimler Enstitüsü, Ankara.

Crimean Court Records (CCR), vol. 11, 13, 17, 20, 31.

Derrida, Jacques. 1994. Specters of Marx: The State of the Debt, the Work of Mourning and the New International. Translated by Peggy Kamuf. New York, NY, and London: Routledge Classics.

Dizer, Muammer. 1986. 'İslâm'da ve Osmanlılarda Saat'. Bilim-Birlik-Başarl, vol. 12 (45): $3-15$.

Doukas. 1975. Decline and Fall of Byzantium to the Ottoman Turks. Translated by Harry J. Magoulias. Detroit, MI: Wayne State University Press.

Eliade, Mircea. 1959. Cosmos and History: The Myth of the Eternal Return. Translated by Willard. R. Trask. New York, NY: Harper \& Brother.

1959. The Sacred \& The Profane: The Nature of Religion. New York, NY: A Harvest Book.

Epstein. Steven A. 1988. 'Business Cycles and the Sense of Time in Medieval Genoa', The Business History Review, vol. 62 (2): 238-60.

Evliya Çelebi. 2006. Evliya Çelebi Seyahatnamesi Topkapı Sarayı Kütüphanesi Bağdat 304 Numaralı Yazmanin Transkripsiyonu-Dizini. Edited by S. A. Kahraman and Y. Dağlı, vol. 2. İstanbul: Yapı Kredi Yayınları.

- 2005. Evliya Çelebi Seyahatnamesi Topkapı Sarayı Kütüphanesi Bağdat 306, Süleymaniye Kütüphanesi Pertev Paşa 462, Süleymaniye Kütüphanesi Hacı Beşir Ağa 452 Numaralı Yazmaların Mukayeseli Transkripsiyonu-Dizini. Edited by S. A. Kahraman, Y. Dağlı and R. Dankoff, vol. 9. İstanbul: Yapı Kredi Yayınları.

Finkel, Caroline. 2005. Osman's Dream: The Story of the Ottoman Empire, 1300-1923. New York: Basic Books.

Glennie, Paul and Nigel Thrift. 2009. Shaping the Day: A History of Timekeeping in England and Wales 1300-1800. Oxford and New York, NY: Oxford University Press.

Grove, Timothy Paul. 2012. A Star in the East: An Ethno-cognitive Study of Georgian Astrology and the Transmission of Knowledge in the Caucasus Region. California: Biola University.

Günalan, Rifat. 2011. Istanbul Kadı Sicilleri, Bâb Mahkemesi 3 Numaralı Sicil (H. 1077/M. 1666-1667). İstanbul: İSAM Yayınları.

Hitzel, Frédéric. 2012. 'De la Clepsydre à l'horloge: l'art de mesurer le temps dans l'empire Ottoman', in Les Ottomans et le temps, edited by François Georgeon and Frédéric Hitzel. Leiden and Boston, MA: Brill: 13-37.

İlhan, Barış. 2007. The Astrology of the Ottoman Empire. İstanbul: Barıș İlhan Publishing. Imber, Colin. 2002. The Ottoman Empire, 1300-1650: The Structure of Power. New York, NY: Palgrave Macmillan.

- The Medieval History Journal, 22, 2 (2019): 343-366 
İnalcık, Halil. 2015. 'Aşıkpaşazâde Tarihi Nasıl Okunmalı?' in Söğ̈̈t ten İstanbul'a, edited by Oktay Özel and Mehmet Öz. İstanbul: İmge Yayınevi: 119-45.

. 2015. Osmanlı Tarihinde Efsaneler ve Gerçekler. İstanbul: NTV Yayınları.

Kadoi, Yuka. 2014. 'Crescent (Symbol of Islam)', The Encyclopaedia of Islam, vol. 3: $47-48$.

Kahramanmaraş. n.d. 'Hatuniye Camii (Şems Hatun Camii)', https://kahramanmaras.bel.tr/ kesfedin/hatuniye-camiisems-hatun-camii (accessed on 28 October 2019).

Kern, Stephen. 1983. The Culture of Time and Space 1880-1918. Cambridge, MA: Harvard University Press.

King, David A. 1991. 'Lunar Crescent Visibility Predictions in Medieval Islamic Ephemerides', in Quest for Understanding: Arabic and Islamic Studies in Memory of Malcolm H. Kerr, edited by. S. M. Seikaly, R. Baalbaki and P. Dodd. Beirut: American University of Beirut: 233-51.

2004. In Synchrony with the Heavens: Studies in Astronomical Timekeeping and Instrumentation in Medieval Islamic Civilization (Studies I-IX) (Vol. I: The Call of the Muezzin). Leiden and Boston, MA: Brill.

Kıyak, Abdülkadir. 2010. 'İslamiyet’ten Önce Türklerde Güneş ve Ay ile İlgili İnanışlar', Karadeniz Uluslararası Bilimsel Dergi, vol. 2 (6): 133-43.

Kuran, Bakara Suresi, 2/189. Ministry for Religious Affairs (Diyanet İşleri Bakanlığı), https://kuran.diyanet.gov.tr/tefsir/sure/2-bakara-suresi.

Lindner, Rudi Paul. 1983. Nomads and Ottomans in Medieval Anatolia. Bloomington, IN: Research Institute for Inner Asian Studies Indiana University.

Manzûr, İbn. n.d. Lisânü'l-Arab. Prepared by Abdullah Ali el-Kebîr-Muhammed Ahmed Hasb Allâh-Hâşim Muhammed eş-Şâzelî, vol 4/5. Cario: Dâr el-Maârif.

Marchant, J. R. V. and Joseph F. Charles. 1953. Cassel's Latin Dictionary. New York, NY: Funk \& Wangnalls Company.

McClellan, James E. and Harold Dorn. 2006. Science and Technology in World History. Baltimore, MD: The Johns Hopkins University Press.

Mehmed Neşri. 1995. Kitâb-ı Cihan-nümâ Neşrî Tarihi. Edited by Faik Reşit Unat and Mehmed A. Köymen, vol. 1. Ankara: Türk Tarih Kurumu.

Meyer, Wolfgang. 1985. İstanbul'daki Güneş Saatleri. İstanbul: Sandoz Kültür Yayınları.

Mubarakpurip, Safiur Rahman. n.d. When the Moon Split: A Biography of Prophet Muhammad. Riyadh, Lahore and Houston, TX: Darussalam.

Müneccimbaşı Ahmed Dede, n.d. Sahaif-ül-Ahbar fî̀ Vekayi-ül-a sâr, vol. 2. Translated by İsmail Erünsal. İstanbul: Tercüman Yayınları.

Oxford Reference. n.d. 'Eclipse', https://www.oxfordreference.com/view/10.1093/oi/ authority.20110803095740827 (accessed on 1 July 2019).

Özdemir, Kemal. 1993. Ottoman Clocks and Watches. İstanbul: A Cultural Publication of TYT Bank.

Özdemir, Rıfat. 2003. 'Çeşitli Kültürlerde Zamanı Ölçme Faaliyetleri ve Bu Konuda Osmanlı Mahkemelerinin Uygulamaları-II'. Türk Dünyası Araştırmaları, vol. 144: 59-87.

Şahin, Hilal. 2006. '77/1 Numaralı Kayseri Şer'iyye Sicili’ (H. 1078/M. 1667) Transkripsiyon ve Değerlendirme. Master Thesis: Erciyes Üniversitesi Sosyal Bilimler Enstitüsü, Kayseri. 
Şen, Ahmet Tunç. 2015. 'Rasattan Takvime: XV/XVI. Yüzyıl Osmanlı Dünyasında Astrolojinin Yeri Üzerine Bazı Gözlemler', in Osmanlı'da İlim ve Fikir Dünyast: Istanbul'un Fethinden Süleymaniye Medreselerinin Kuruluşuna Kadar, edited by Ömer Mahir Alper and Mustakim Arıcı. Istanbul: Klasik Yayınları: 227-49.

- 2006. 'Astrology in the Service of the Empire: Knowledge, Prognostication, and Politics at the Ottoman Court, 1450s-1550s.' PhD Dissertation: The University of Chicago: Chicago, IL.

The London Gazette. 1671. https://www.thegazette.co.uk/London/issue/600/data.pdf (accessed on 1 July 2019).

Tunalı, Gülçin. 2012. 'An Ottoman Astrologer at Work: Sadullah el-Ankaravi and the Everyday Practice of İlm-i Nücum', in Les ottomans et le temps, edited by François Georgeon and Frédéric Hitzel. Leiden and Boston, MA: Brill, 2012.

Tursun Beg. 1978. The History of Mehmed the Conqueror: Text Published in Facsimile with English Translation. Translated by Halil İnalcık and Rhoads Murphey. Minneapolis, Chicago: Bibliotheca Islamica.

Tursun Bey. n.d. Fatih 'in Tarihi (Tārih-i Ebul Feth). İstanbul: Tercüman Yayınları.

Vatin, Nicolas. 2012. 'L'Homme d'état ottoman, maitre du temps: la crise de 1566', in Les ottomans et le temps, edited by François Georgeon and Frédéric Hitzel. Leiden and Boston, MA: Brill: 77-98.

Wheatcroft, Andrew. 2008. The Enemy at the Gate: Habsburgs, Ottomans and the Battle for Europe. New York, NY: Basic Books.

Yücel, İrfan. 1998. 'Hilâl'. TDV İslâm Ansiklopedisi, vol. 18: 1-11. 